OPEN ACCESS

Edited by:

Nichol E. Holodick,

The Feinstein Institute for Medical Research, USA

Reviewed by:

Ronald B. Corley,

Boston University School of

Medicine, USA

David Nemazee,

The Scripps Research Institute, USA

*Correspondence:

Gabriel K. Pedersen gabriel.pedersen@ki.se;

Gunilla B. Karlsson Hedestam

gunilla.karlsson.hedestam@ki.se

${ }^{\dagger}$ Gabriel K. Pedersen and

Monika Ádori contributed equally.

Specialty section:

This article was submitted to B Cell Biology,

a section of the journal

Frontiers in Immunology

Received: 23 November 2015 Accepted: 12 February 2016

Published: 01 March 2016

Citation:

Pedersen GK, Ádori M, Stark JM, Khoenkhoen S, Arnold C, Beutler B and Karlsson Hedestam GB (2016)

Heterozygous Mutation in I $\mathrm{kBNS}$ Leads to Reduced Levels of Natural IgM Antibodies and Impaired Responses to T-Independent Type 2 Antigens.

Front. Immunol. 7:65. doi: 10.3389/fimmu.2016.00065

\section{Heterozygous Mutation in IאBNS Leads to Reduced Levels of Natural IgM Antibodies and Impaired Responses to T-Independent Type 2 Antigens}

\author{
Gabriel K. Pedersen ${ }^{\text {*t }}$, Monika Ádori ${ }^{1 \dagger}$, Julian M. Stark ${ }^{1}$, Sharesta Khoenkhoen ${ }^{1}$, \\ Carrie Arnold ${ }^{2}$, Bruce Beutler ${ }^{3}$ and Gunilla B. Karlsson Hedestam ${ }^{1 *}$
}

${ }^{1}$ Department of Microbiology, Tumor and Cell Biology, Karolinska Institutet, Stockholm, Sweden, ${ }^{2}$ Department of Genetics, The Scripps Research Institute, La Jolla, CA, USA, ${ }^{3}$ Center for the Genetics of Host Defense, University of Texas Southwestern Medical Center, Dallas, TX, USA

Mice deficient in central components of classical NF-kB signaling have low levels of circulating natural IgM antibodies and fail to respond to immunization with T-independent type 2 (TI-2) antigens. A plausible explanation for these defects is the severely reduced numbers of B-1 and marginal zone B (MZB) cells in such mice. By using an ethyl- $N$ nitrosourea mutagenesis screen, we identified a role for the atypical $\|_{\kappa} B$ protein $\mid \kappa B N S$ in humoral immunity. IkBNS-deficient mice lack B-1 cells and have severely reduced numbers of MZB cells, and thus resemble several other strains with defects in classical $\mathrm{NF}-\mathrm{\kappa B}$ signaling. We analyzed mice heterozygous for the identified IкBNS mutation and demonstrate that these mice have an intermediary phenotype in terms of levels of circulating lgM antibodies and responses to Tl-2 antigens. However, in contrast to mice that are homozygous for the IkBNS mutation, the heterozygous mice had normal frequencies of B-1 and MZB cells. These results suggest that there is a requirement for IкBNS expression from two functional alleles for maintaining normal levels of circulating natural lgM antibodies and responses to TI-2 antigens.

Keywords: B-1 cells, transitional B cells, $n f k b i d$, ІкBNS, NF-кB

\section{INTRODUCTION}

Innate-like B cells play significant roles in the early defense against pathogens and, at steady state, anti-inflammatory mediators, such as IL-10, and polyreactive IgM antibodies are secreted by these cell subsets to help maintain homeostasis. There is a clear division of labor between the different innate-like B cells. B-1a cells are thought to secrete most of the natural polyreactive antibodies found in the serum (1). Innate response activator B cells exert protective effects against sepsis by secreting GM-CSF (2). Marginal zone B (MZB) cells, through their location at the interface between the blood and the immune system, help initiate responses against blood-borne antigens [reviewed in Ref. (3)]. B cells regulate inflammation through various mechanisms, including production of anti-inflammatory cytokines, such as IL-10 and IL-35 $(4,5)$. The main IL-10 producing innate-like B cells, collectively named B10, are found within the MZB (5) and B-1a cell subsets $(4,6)$. Innate-like B cells are also 
pivotal for the response against viral and bacterial infections (1). Particularly, the innate-like B cell subsets B-1b and MZB cells are the predominant responding $\mathrm{B}$ cells to T-independent type 2 (TI-2) antigens found on the surface of a number of pathogens, such as Streptococcus pneumoniae, Haemophilus influenzae, and Neisseria meningitides $(3,7,8)$.

In addition to their distinct roles in homeostasis and response to different stimuli, the innate-like B cell subsets also have distinct developmental pathways. B-1 cells are generated readily from the yolk salk, paraaortic splanchnopleura, and liver during early fetal development $(9,10)$, while these organs are less effective at generating follicular B cells. In contrast, hematopoietic stem cells from adult bone marrow predominantly generate follicular B and MZB cells (9), collectively referred to as B-2 cells. Immature B cells mature in the spleen and undergo selection at various transitional stages before becoming naive B cells (11). B-2 cells are continuously replenished from the adult bone marrow and diverge into follicular B cells and MZB cells at the transitional B cell stage (12, 13). B-1 cells may develop from a separate progenitor population (14) and mature via a phenotypically distinct B-1 transitional $\mathrm{B}$ cell intermediate, which is found at high frequencies in the spleen of neonatal mice (15). The different B cell subsets require distinct stimuli for development and maintenance. For example, MZB cells are dependent on Notch signaling, and therefore mice with impaired Notch 2 completely lack MZB cells. However, Notch signaling is not required for B-1 or follicular B cell development (12). The distinct B cell subsets also show different requirements for NF- $\kappa \mathrm{B}$ signaling (16).

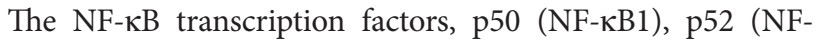
$\kappa \mathrm{B} 2$ ), p65 (RelA), c-Rel (Rel), and RelB, regulate transcription by binding to promoters of target genes. p50 and p52 induce gene transcription by forming heterodimers with p65, c-Rel, or RelB, all of which contain a transactivation domain. In contrast, homodimers of p50 or p52 lack a transactivation domain and thus generally function as repressors of transcription. In classical $\mathrm{NF}-\kappa \mathrm{B}$ signaling, the NF- $\mathrm{\kappa B}$ transcription factors are sequestered in the cytoplasm as dimers of p50:p65 by a protein family known as inhibitors of $\kappa \mathrm{B}$ (I $\kappa \mathrm{B})$, including I $\mathrm{\kappa B}-\alpha, \mathrm{I} \kappa \mathrm{B}-\beta, \mathrm{I} \kappa \mathrm{B}-\epsilon$, and the $\mathrm{p} 50$ precursor $\mathrm{p} 105$. The $\mathrm{I} \kappa \mathrm{B}$ proteins are characterized by their ankyrin repeat structure, which functions to mask nuclear localization signals (17). IאB kinases (IKK), IKK- $\alpha$ (IKK1), IKK- $\beta$ (IKK2), and IKK- $\gamma$ (NF-kappa-B essential modulator, NEMO), target IкBs for polyubiquitination and proteasomal degradation, thereby

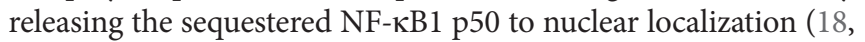
19). In lymphocytes, this requires the CARD11, BCL-10, MALT1 (CBM) complex. Through an alternative NF- $\kappa B$ signaling pathway, NF- $\kappa \mathrm{B}$-inducing kinase (NIK) can activate IKK- $\alpha$, facilitating proteasomal processing of NF- $\kappa B 2 \mathrm{p} 100$. This ultimately leads to nuclear localization of NF- $\mathrm{BB}$ p52/RelB (20). A number of atypical $\mathrm{I} \kappa \mathrm{B}$ proteins have recently been identified, defined by their ankyrin

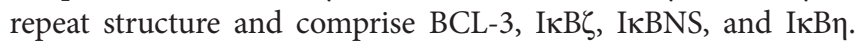
Atypical I $\mathrm{B}$ proteins may either augment or repress transcription depending on cell type, context, and timing. Recent studies have revealed important roles of atypical I $\mathrm{B}$ proteins in lymphopoiesis and immunological responses [reviewed in Ref. (21)].

Classical NF- $\kappa \mathrm{B}$ signaling is required for the generation of $\mathrm{B}-1$ cells, particularly the B-1a subset, which is absent in a number of mouse strains where this pathway has been ablated [reviewed in Ref. (22)]. Reduction in MZB cell numbers is also seen in the absence of classical NF- $\mathrm{BB}$ signaling, while follicular B cells are less affected $(23,24)$. Although relatively little is known about the function of atypical I $\mathrm{KB}$ proteins in B cell development, roles for BCL-3 and IкBNS have recently been demonstrated. BCL-3 deficiency leads to increased numbers of MZB cells (25), while decreased B-1 and MZB cellularity was observed upon overexpression of BCL-3 (26). Absence of functional IкBNS leads to reductions in $\mathrm{B}-1 \mathrm{~b}$ and $\mathrm{MZB}$ cell frequencies $(27,28)$ and complete absence of B-1a cells, while follicular B cell frequencies are intact $(15,28)$. In terms of B cell lymphopoiesis, IкBNS-deficient mice thus resemble other mouse strains with impaired classical NF- $\kappa B$ signaling. In addition to the role of classical NF- $\kappa B$ signaling in $\mathrm{B}$ cell development, it is also required for normal function of mature B cells. B cells from p50, BCL10, and CARMA1-deficient mice display reduced proliferation and antibody production to anti-IgM, anti-CD40, or LPS compared to wild-type (wt) cells in vitro (29-31).

Mice with impaired classical NF- $\mathrm{B}$ signaling have reduced levels of circulating natural IgM and IgG3 antibodies and fail to mount antibody responses to TI-2 antigens in vivo. We previously described that mice lacking functional IкBNS due to a mutation in the nfkbid gene (bumble mice) also display reduced IgM and IgG3 levels and fail to respond to immunization with NP-ficoll $(27,28)$. Whether the impaired antibody response in mice deficient in classical NF- $\kappa \mathrm{B}$ pathway signaling is a consequence of the reduced numbers of B-1 and MZB cells or is due to defects in B cell function remains unknown. Here, we demonstrate that the lack of IкBNS even at the heterozygous state $(\mathrm{I \kappa BNS}+/ b m b)$ led to severely reduced antibody responses against TI-2 antigens, suggesting haploinsufficiency for IкBNS in the response to such antigens. Interestingly, unlike homozygous bumble mice, the heterozygous mice displayed apparently normal frequencies and numbers of MZB and B-1 cells. This indicates that the reduced responses to TI-2 antigens in these mice are due to a direct requirement of IкBNS in response to $\mathrm{B}$ cell receptor engagement rather than a secondary effect due to lack of responding cells.

\section{MATERIALS AND METHODS}

\section{Mice}

Mice were housed and bred at the animal research facility, MTC, Karolinska Institutet. Bumble mice, generated by $N$-ethyl- $N$ nitrosourea (ENU) mutagenesis of C57BL/6J mice, and their wt C57BL/6J counterparts were described previously (28). Animal studies were conducted with Committee for Animal Ethics (Stockholms Norra Djurförsöksetiska nämnd) approval.

\section{Cell Preparation}

Splenocytes were prepared as a single cell suspension using a $70-\mu \mathrm{m}$ cell strainer. Peritoneal cells were isolated by flushing with cold PBS/1\% FBS (5-10 ml). Peritoneal cells were discarded if contaminated with blood. Cell suspensions were diluted in RPMI-1640 supplemented with $2 \mathrm{mM} \mathrm{L-glutamine,} \mathrm{penicillin}$ 
(100 IU)-streptomycin $(100 \mu \mathrm{g} / \mathrm{ml})$, and $10 \%$ fetal bovine serum (complete RPMI). Splenocyte cell suspensions were washed once in $\mathrm{Ca}^{2+}$-free $\mathrm{Mg}^{2+}$-free PBS and treated with red blood cell lysis buffer before further processing. B cells were isolated from the spleen using the B cell isolation kit and from the peritoneal cavity using the Pan-B cell isolation kit (Stemcell Technologies). The purity of the isolated populations was $\geq 90 \%$.

\section{Immunization}

Mice were immunized with 50- $\mu \mathrm{g}$ NP (40)-ficoll (Biosearch Technologies) or a 1:10 dilution of Pneumovax ${ }^{\circledR}$ (Merck \& Co.) corresponding to $0.5 \mu \mathrm{g}$ of each polysaccharide antigen. The antigens were diluted in PBS and $100 \mu \mathrm{l}$ was injected intraperitoneally (i.p.).

\section{Adoptive Transfer}

Isolated peritoneal B cells $\left(2 \times 10^{6}\right.$ cells $)$ from wt or heterozygous mice were mixed with $50 \mu \mathrm{g} \mathrm{NP}(40)$-ficoll and injected i.p. into bumble mice. Splenic B cells $\left(30 \times 10^{6}\right.$ cells $)$ were injected i.v.

\section{ELISA}

ELISA was performed by coating ELISA plates (Nunc) with polysaccharide antigens: $500 \mathrm{ng} /$ well of NP (25) conjugated with BSA (Biosearch Technologies) or the pneumococcal polysaccharide antigens Type 1 161-X $\mathrm{X}^{\mathrm{TM}}$ or Type 3 169-X $\mathrm{X}^{\mathrm{TM}}$ (both ATCC) or 1:100 dilution of Pneumovax (corresponding to $50 \mathrm{ng} /$ well of each antigen contained in the vaccine). To measure total IgM and IgG3 levels, plates were coated with unconjugated anti-IgM or anti-IgG3 (Southern Biotech). Plates were incubated overnight $\left(4^{\circ} \mathrm{C}\right)$. Following washing (PBS $+2 \%$ Tween 20$)$ and blocking for $1 \mathrm{~h}$ with PBS containing $2 \%$ dry milk, serum was added in threefold serial dilutions in blocking buffer and incubated for $1.5 \mathrm{~h}$ at room temperature (RT) before addition of secondary antibody HRP-coupled anti-IgM or IgG3 (Southern Biotech). The assay was developed with TMB substrate (KPL) followed by $1 \mathrm{M} \mathrm{H}_{2} \mathrm{SO}_{4}$ and the OD was read at $450 \mathrm{~nm}$ using an Asys Expert 96 ELISA reader (Biochrom).

\section{ELISpot Assay for Detection of Antibody- Secreting Cells}

Detection of total IgM and NP-specific IgM producing cells was performed using enzyme-linked immunosorbent spot (ELISpot) assay. MultiScreen-IP filter plates (Millipore) were pretreated with $70 \%$ ethanol and washed in sterile PBS. Plates were coated with $5 \mu \mathrm{g} / \mathrm{ml}$ anti-mouse IgM (Southern Biotech) or $5 \mu \mathrm{g} / \mathrm{ml}$ of NP (25), conjugated with BSA (Biosearch Technologies), diluted in PBS, and incubated overnight at $4^{\circ} \mathrm{C}$. The following day, plates were washed in sterile PBS, blocked in complete RPMI medium with 50- $\mu \mathrm{M} 2$-mercaptoethanol and 10-mM HEPES for $1 \mathrm{~h}$ at $37^{\circ} \mathrm{C}$, and the indicated cell numbers added in triplicate. Plates were incubated for $17 \mathrm{~h}$ at $37^{\circ} \mathrm{C}$ in $5 \% \mathrm{CO}_{2}$. Cells were then removed by washing in PBS and $0.1 \mu \mathrm{g} /$ well of biotinylated anti-mouse IgM (Mabtech) diluted in PBS was added to the wells. After $2 \mathrm{~h}$ of incubation at RT, plates were washed and developed with $100 \mu \mathrm{l}$ of 5-bromo-4-chloro-3-indolyl phosphate/NBT-plus substrate (Mabtech). The reaction was stopped when distinct spots could be observed, by rinsing the plates extensively in tap water. Spots were counted by ELISpot reader (CTL) and analyzed using the Biospot suite (CTL).

\section{Flow Cytometry}

Cells were incubated with Fc block (anti-CD16/32, BD) and stained with fluorochrome-conjugated monoclonal antibodies in $\mathrm{PBS} / 2 \% \mathrm{FBS}$ using the following antibodies: CD5 Brilliant Violet 421 (S3-7.3), CD19 PE (1D3), CD19 FITC (1D3), CD23 Brilliant Violet 421 (B3B4), CD21 APC (7G6), CD43 APC (S7) (all BD), B220 APC-eFluor 780 (RA3-6B2), CD93 APC (AA4.1) (all eBioscience), and IgM FITC (polyclonal) (Southern Biotech). Data were analyzed in FlowJo v9.6.4 (Treestar).

\section{Statistics}

Differences between groups were analyzed by a Mann-Whitney test (GraphPad Prism v6.0f).

\section{RESULTS}

\section{Heterozygous Bumble Mice Have Reduced Serum IgM Levels and Responses to the TI-2 Antigen NP-Ficoll}

In an ENU mutagenesis screen for antibody response defects, we identified a role of IкBNS for B cell development and function. We observed that mice homozygous for a specific mutation in $n f k b i d$ lacked responses to the TI-2 antigen NP-ficoll and had reduced levels of circulating IgM and IgG3 antibodies (28). These mice, named bumble, were found to have a $\mathrm{T} \rightarrow \mathrm{G}$ transversion in the conserved donor splice site in the fourth intron of $n f k b i d$, the gene encoding I $\kappa \mathrm{BNS}$. This mutation is predicted to prevent splicing of the fourth intron from the nfkbid transcript, resulting in a premature stop codon after exon 4 . Such a transcript would likely be targeted for nonsense-mediated decay or encode only 65 of 327 amino acids (aa) encoded by full-length $n f k b i d$, and therefore not be expected to retain any function. The phenotype for bumble mice was copied in mice with a targeted mutation in the $n f k b i d$ gene (28) and was similar in IкBNS knockout mice (27). Here, we report that mice heterozygous for the bumble mutation displayed reduced NP-specific IgM and IgG3 antibody responses after NP-ficoll immunization (Figure 1A). Furthermore, when analyzing isolated splenocytes for NP-specific IgM antibody-secreting cells (ASC), we observed significantly $(p<0.001)$ lower numbers in bumble heterozygous compared to wt mice (Figure 1B). To test if the TI-2 antigen response defect in heterozygous bumble mice was due to a B cell intrinsic defect, we transferred isolated splenic and peritoneal B cells to bumble mice and immunized them with NP-ficoll. Bumble mice that had not received isolated $\mathrm{B}$ cells did not respond to immunization, whereas bumble mice that had received wt $\mathrm{B}$ cells did. Bumble mice that had received B cells from heterozygous bumble mice had an intermediate response to NP-ficoll immunization, suggesting that the defective antibody response to TI-2 antigens in heterozygous bumble mice is due to a B cell intrinsic defect (Figure 1C). Similarly to bumble homozygotes, mice with the heterozygous bumble mutation displayed significantly reduced total serum levels of IgM and IgG3 

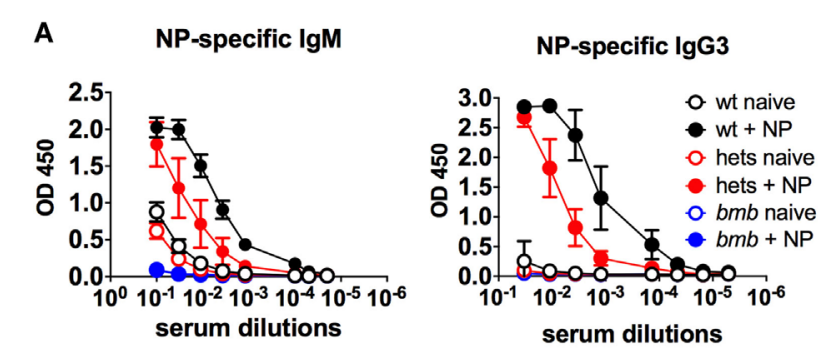

\section{B NP-specific IgM antibody secreting cells}

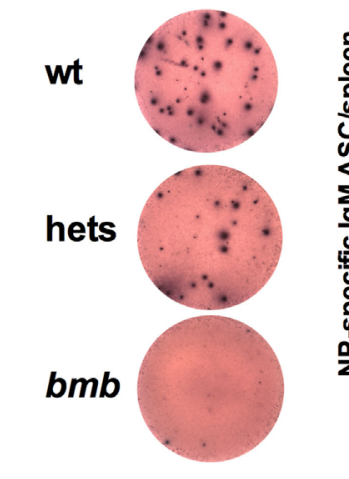

C NP-specific lgM
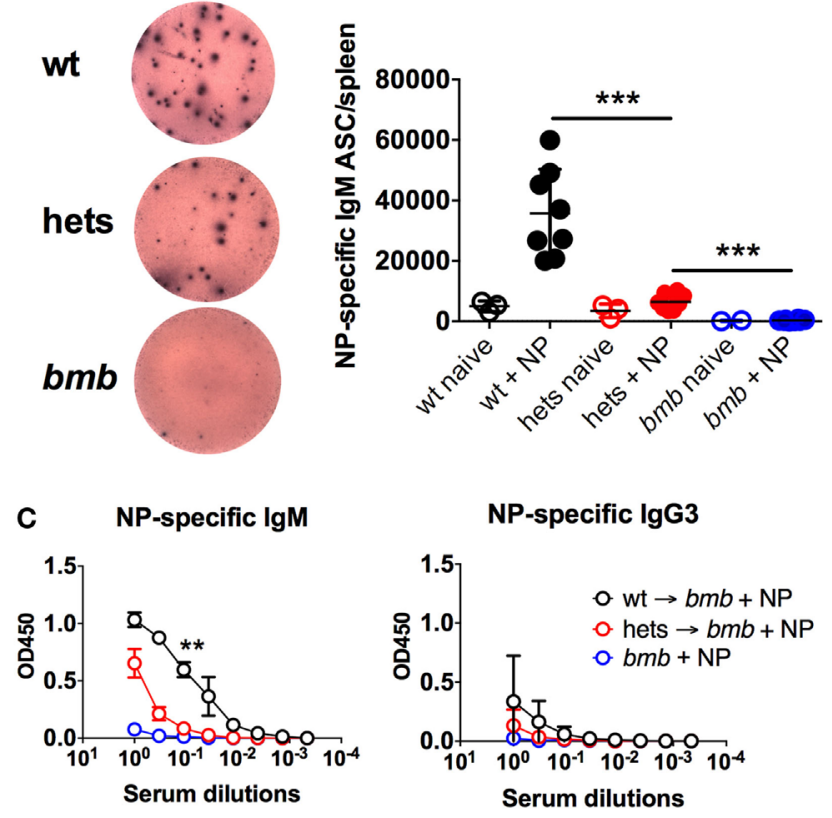

D Total IgM
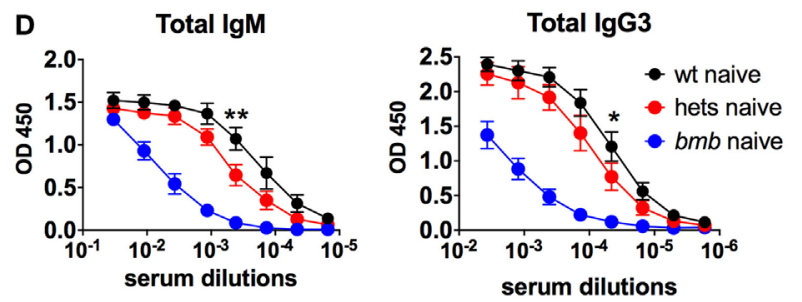

FIGURE 1 | Heterozygous bumble mice have reduced serum IgM levels and responses to $\mathrm{Tl}-2$ antigens. (A) Mice were immunized with $50 \mu \mathrm{g}$ of NP-ficoll intraperitoneally and sacrificed after 6 days. NP-specific serum IgM and IgG3 were determined by ELISA. (B) NP-specific IgM antibody-secreting cells were determined by ELISpot. Left panel displays representative wells of wild-type (wt), heterozygous (hets), and bumble (bmb). (C) Isolated peritoneal B cells $\left(2 \times 10^{6} \mathrm{cells}\right)$ from wild-type or heterozygous bumble mice were mixed with 50- $\mu \mathrm{g} \mathrm{NP} \mathrm{(40)-ficoll} \mathrm{and}$ injected i.p. into bumble mice. The recipient bumble mice then received splenic $B$ cells $\left(30 \times 10^{6}\right.$ cells) from wild-type or heterozygous mice injected i.v. NP-specific serum IgM and IgG3 were determined by ELISA 6 days later. (D) Total serum IgM and IgG3 were determined by ELISA. Figures represent 8- to 16-week-old aged-matched mice with three to eight per group and results are representative of three $\mathbf{( A , B )}$ or two (C) independent experiments. Graphs display mean + SD. Statistically significant differences between bumble, bumble heterozygotes, and wt mice are indicated by ${ }^{*} p<0.05,{ }^{* *} p<0.01$, and ${ }^{* * *} p<0.001$ by Mann-Whitney test.
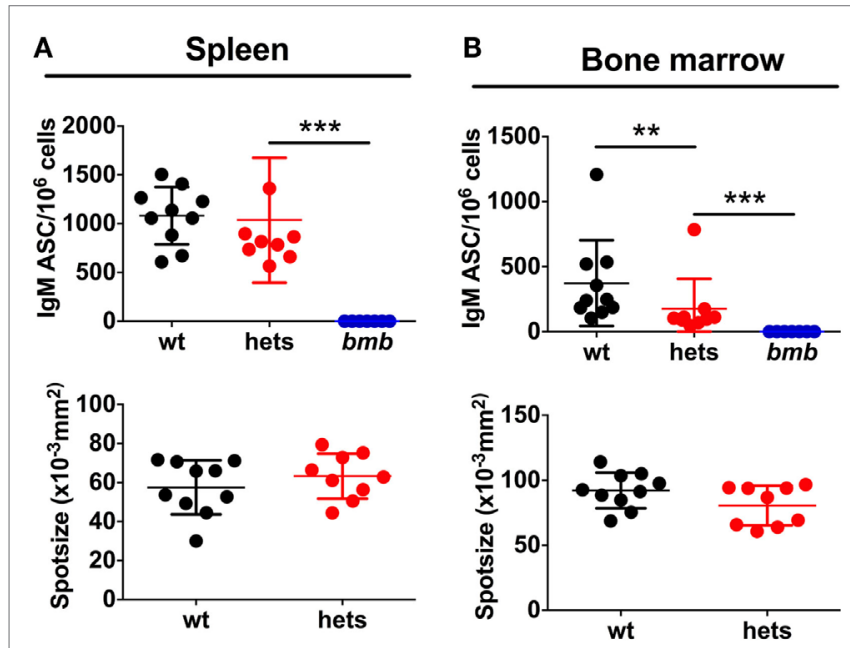

FIGURE 2 | Heterozygous bumble mice have fewer IgM-secreting B cells. Cell suspensions in serial dilutions were plated on ELISpot plates coated with anti-lgM. IgM antibody-secreting cells (ASC) in (A) spleen and (B) bone marrow. Upper panels display IgM ASCs per $10^{6}$ cells and lower panels indicate mean spot size. Spot size is influenced by the number of spots per well. Therefore, wells containing similar numbers of spots across groups were used to calculate spot size (range 10-30 spots for bone marrow and 30-70 for spleen). Data were compiled from two experiments.

antibodies $(p<0.05)$ (Figure 1D). Thus, relative to homozygous bumble mice and wt mice, heterozygous bumble mice presented with an intermediary phenotype in terms of response to NP-ficoll and levels of circulating IgM and IgG3 antibodies.

\section{Fewer IgM Antibody-Secreting Cells in Heterozygous Bumble Mice}

We next asked if the reduced IgM levels in heterozygous bumble mice were due to fewer IgM-secreting B cells or if less IgM was produced per cell. To assess this, we performed ELISpot for total IgM producing splenic and bone marrow B cells. The same numbers of cells were plated from wt, heterozygous, and homozygous bumble mice. As expected, no IgM ASCs were detected from homozygous bumble mice. The fraction of splenic B cells spontaneously secreting IgM in heterozygous bumble mice was slightly lower than in wt mice, although this difference was not statistically significant ( $p=0.23$ ) (Figure 2A). The frequency of IgM ASCs in bone marrow was significantly lower in heterozygous bumble mice than in wt mice $(p<0.01)$. As an indication of the amount of IgM produced per IgM ASC, we evaluated the mean spot size. We observed no measurable differences in mean spot size between heterozygous and wt mice (Figure 2B). These data indicate that the reduced levels of natural IgM antibodies in the serum is due to fewer IgM ASCs in the heterozygous bumble rather than less IgM secreted per ASC.

\section{Heterozygous Bumble Mice Have Normal Frequencies of the Major B Cell Subsets}

The main responding $B$ cell subsets against TI-2 antigens are B-1b cells and MZB cells $(3,7,8)$, while B-1a cells are believed 
to produce most of the natural $\operatorname{IgM}$ antibodies found in the serum at steady state (1). Homozygous bumble mice had normal numbers of follicular B cells, but completely lacked B-1a cells, and displayed a severe reduction in the frequencies of $\mathrm{B}-1 \mathrm{~b}$ and MZB cells $(15,28)$. Transfer of wt peritoneal cells to bumble mice completely restored serum natural IgM levels and partly restored the antibody response to immunization with NP-ficoll (15). This suggested that the lack of B-1b cells in homozygous bumble mice formed the basis for the impaired response to T-independent antigens. To investigate if heterozygous bumble mice have defects in B cell development, we used the following strategy to phenotypically distinguish the major B cell subsets. B220 is expressed by all B-2 cells (MZB and follicular B cells), but at lower levels on most B-1 cells. CD11b and CD43 are expressed by B-1 cells, and CD5 is expressed by the B-1a cell subset. CD23 is expressed by B-2 cells, but not MZB cells, while MZB cells express high levels of CD21. When analyzing the different B cell subsets in heterozygous bumble mice, we found that neither overall splenic B cell nor MZB cell numbers were significantly different between wt mice and heterozygous bumble mice. In contrast, mice homozygous for the bumble mutation had significantly reduced MZB cell numbers as expected $(p<0.01)$ (Figure 3A). The increased surface IgM level seen in homozygous bumble mice (28) was not observed in the heterozygous state (Figure 3B). Furthermore, homozygous bumble mice have decreased frequencies of transitional T3 B cells (15), while in heterozygous mice, the T3 B cell frequencies were similar to those of wt mice (Figure 3C). No differences in bone marrow B cell progenitor populations were observed between wt, homozygous, and heterozygous bumble mice (Figure 3D). As we reported previously, homozygous bumble mice completely lacked B-1a cells and had significantly reduced B-1b cell frequencies $(p<0.01)(15)$. In contrast, peritoneal B-1a and B-1b cell frequencies were similar in wt and heterozygous bumble mice (Figure 4A). Similarly, bone marrow B-1a cell and spleen B-1a cell frequencies were indifferent between heterozygous bumble and wt mice (Figures 4B,C). Overall, these data indicate that the development and maintenance of all the major B cell subsets occur normally in heterozygous bumble mice.

\section{Impaired Antibody Response to the TI-2 Vaccine Pneumovax in Heterozygous Bumble Mice}

We next investigated if the impaired response to TI-2 antigens in heterozygous bumble mice would extend to the clinically relevant human polysaccharide vaccine Pneumovax. To this end, wt, heterozygous, and homozygous bumble mice were immunized with Pneumovax intraperitoneally. By 6 days post-immunization, wt mice mounted a strong antibody response against the Pneumovax vaccine antigens. No response was observed in homozygous bumble mice, while heterozygous bumble mice displayed an intermediary response (Figure 5A). We also investigated the Pneumovax-elicited responses to the polysaccharide antigens type 1 161-X (Figure 5B) and type $3169-X$ (Figure 5C). Similarly to total Pneumovax-specific antibodies, the responses against both polysaccharides were significantly diminished in heterozygous bumble mice compared to in wt mice $(p<0.01)$.

\section{DISCUSSION}

The data presented here demonstrate that a heterozygous mutation in IкBNS causes a significant impairment of B cell function. Mice that express one wt allele and one allele containing the bumble mutation in $n f k b i d$ had diminished antibody responses to T-independent type II antigens and reduced levels of circulating natural IgM and IgG3 antibodies. The bumble mutation causes a premature stop codon after exon 4 in the nfkbid gene and the resulting transcript encodes only 65 of the 327 aa of the full-length IкBNS (28). The resulting mRNA transcript is likely targeted for degradation by nonsense-mediated decay. Thus, the spontaneous secretion of natural antibodies and responses to TI-2 antigens in bumble heterozygotes are likely impaired as a result of haploinsufficiency for the nfkbid gene.

Previous work has shown that $\mathrm{p} 50^{-/-}, \mathrm{BCL} 10^{-/-}$, and $\mathrm{I} \kappa \mathrm{B} \alpha$ hypermorphic mice fail to respond to immunization with TI-2 antigens $(32,33)$, illustrating that this defect is a general feature of deficiency in the classical NF- $\kappa B$ signaling pathway. Similar to

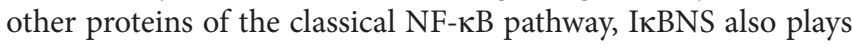
an important role for maintaining normal levels of serum natural antibodies and for the antibody response against TI-2 antigens $(27,28)$. Notably, the major B cell subsets responsible for natural antibody production and response to TI- 2 antigens, B- 1 and MZB cells are lacking in mice with impaired classical NF- $\kappa \mathrm{B}$ signaling, which is also similar for mice with non-functional IкBNS $(15,27$, 28). It was therefore interesting that heterozygous bumble mice had decreased serum IgM and IgG3 levels and defective responses to TI-2 antigens, despite having apparently normal numbers and frequencies of B-1 and MZB cells. This suggested that the lack of specific $B$ cell subsets is not the sole reason for the reduced levels of natural antibodies and response to TI-2 antigens in IкBNSdeficient mice. Rather, this indicated a more direct role of IкBNS for these aspects of immunity downstream of B cell receptor signaling. Particularly, the lack of response to TI-2 antigens of heterozygous bumble mice may be due to a B cell intrinsic defect in activation or ASC differentiation, although it is also possible that the BCR repertoire may be altered when I $\mathrm{BNNS}$ is only expressed from one allele. We did not observe any reduction in B-1a, MZB, or follicular B cell numbers in heterozygous bumble mice, suggesting that one functioning allele of $n f k b i d$ is enough to facilitate normal B cell development. However, we cannot rule out the possibility that a modest impairment of B cell development is masked by homeostatic proliferative mechanisms or altered bone marrow output to control distribution of immune cells (34).

There are only few reports of heterozygous mutations in the NF- $\kappa \mathrm{B}$ pathways leading to loss of B cell function. Hypermorphic heterozygous mutations in $\mathrm{I} \kappa \mathrm{B} \alpha$ cause impaired antibody responses (33) and CARMA1-deficient mice lacking CARD ( $\triangle$ CARD) showed defective B cell proliferation at the heterozygous state (35). Since $\triangle C A R D$ was found to act as a dominant-negative inhibitor of TCR-induced NF- $\mathrm{B}$ activation, the impaired B cell function in heterozygous $\triangle \mathrm{CARD}$-deficient mice may be due to the truncated CARMA1 protein interfering with function of the wt protein (36). Protein kinase C- $\beta$ (PKC $\beta$ ) initiates a phosphorylation cascade that activates the CBM complex downstream $\mathrm{BCR}$ signaling. Heterozygous missense mutations in the gene 

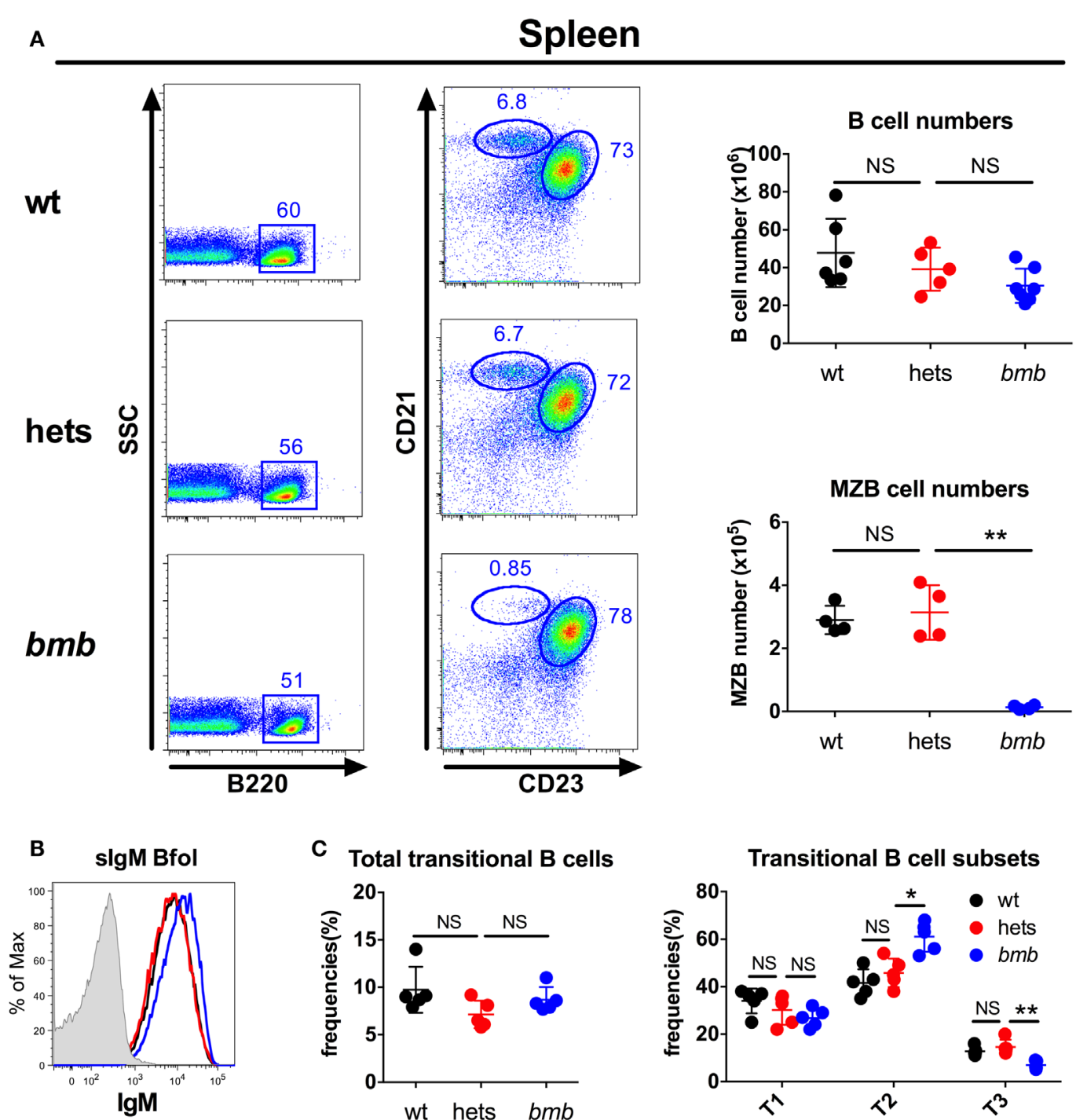

C Total transitional B cells

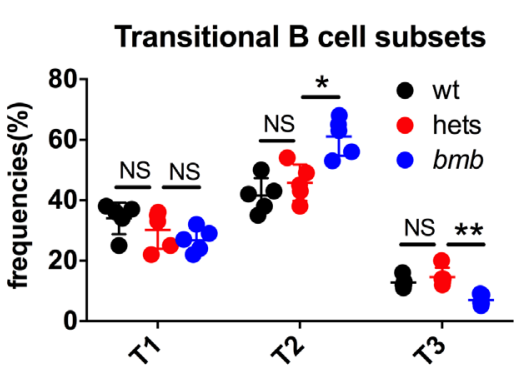

\section{Bone marrow}
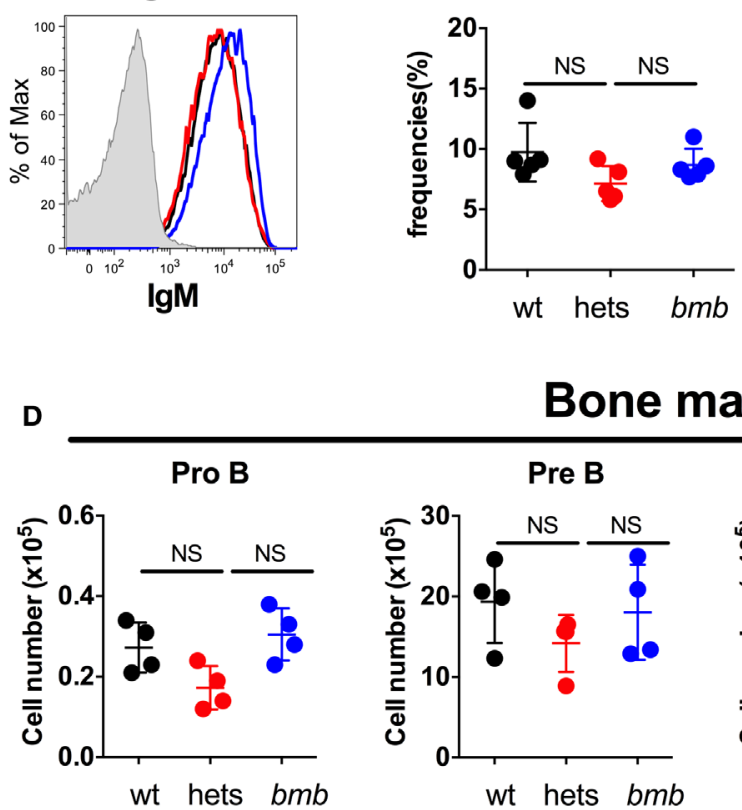

FIGURE 3 Heterozygous bumble mice have normal frequencies of the major B cell subsets. Total B cells, marginal zone B cells (MZB), and transitional $B$ cells were stained by FACS in wild-type (wt), heterozygous (hets), and bumble (bmb) mice. (A) Left panel: representative staining of marginal zone B cells (MZB, $\mathrm{B} 220^{+}, \mathrm{CD}^{-} 3^{-}$, and $\left.\mathrm{CD} 21^{\mathrm{hi}}\right)$ and follicular B cells $\left(\mathrm{B} 22 \mathrm{O}^{+}, \mathrm{CD} 23^{+}\right.$, and $\left.\mathrm{CD} 21^{+}\right)$. Right panel: total B cell $\left(\mathrm{B} 22 \mathrm{O}^{+}\right)$and $\mathrm{MZB}$ cell numbers. (B) Representative staining of surface lgM (slgM) on wt (black), heterozygous (blue), and bumble (blue) follicular B cells. (C) Splenic transitional B cells (B220 ${ }^{+}$and CD93 ${ }^{+}$), further subdivided into

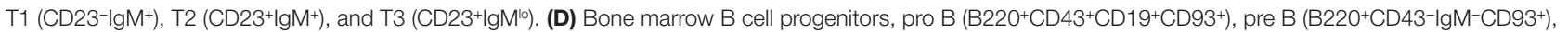

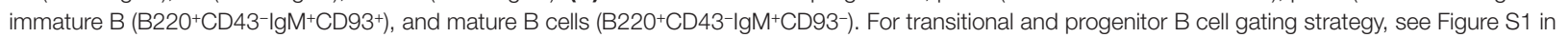
Supplementary Material. Figures represent 8- to 16-week-old mice with four to seven mice per group, and results are representative of at least two independent experiments. Graphs display mean + SD. Statistically significant differences between bumble, bumble heterozygotes, and wt mice are indicated by ${ }^{*} p<0.05$ by Mann-Whitney test. 

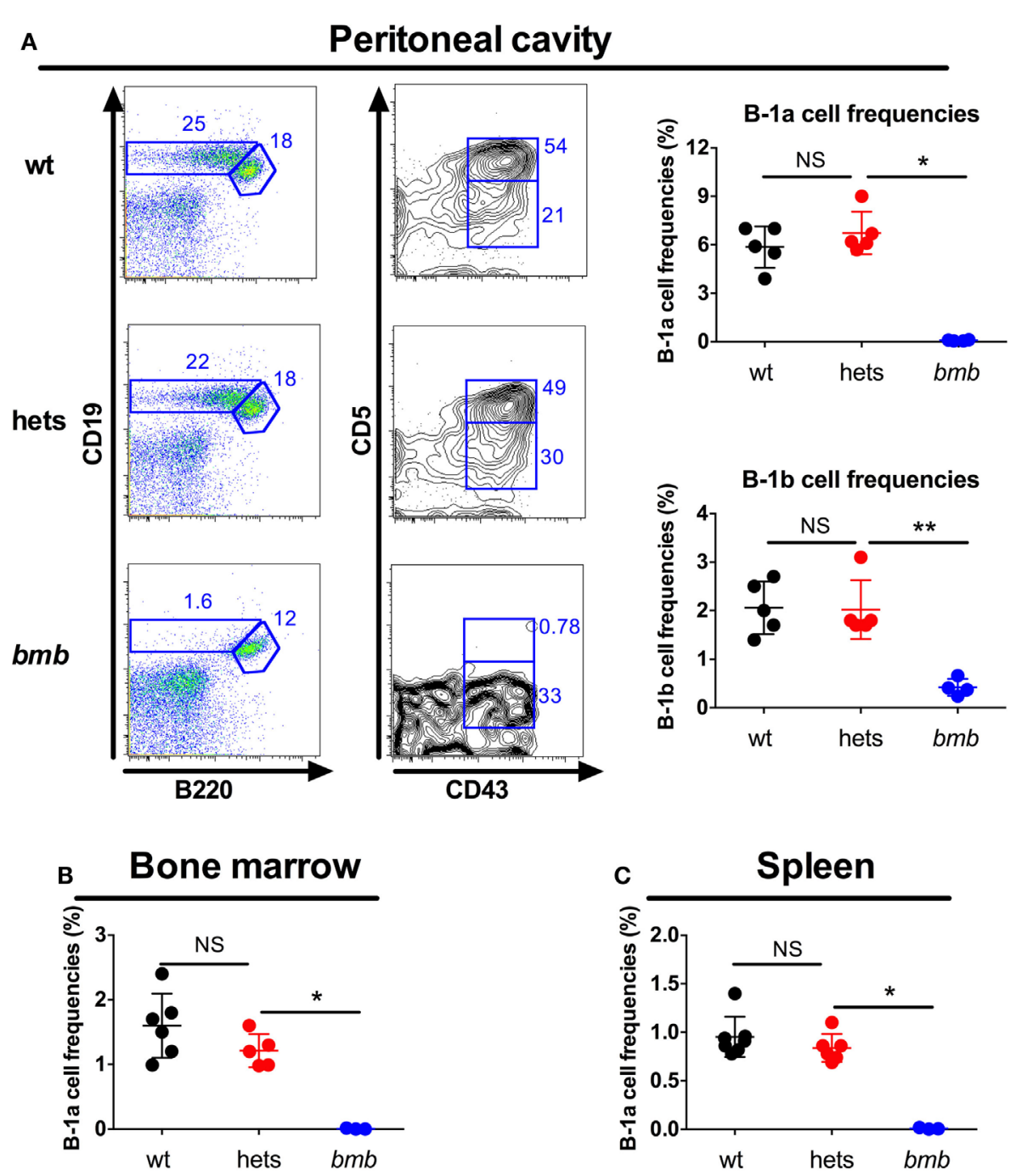

FIGURE 4 | Heterozygous bumble mice have normal frequencies of B-1 cells. Wild-type (wt), heterozygous bumble (hets), and bumble (bmb) cells were

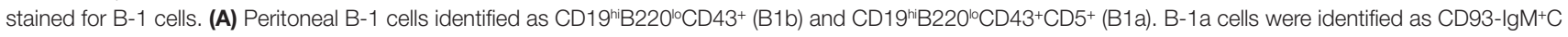
D19hi B220 ${ }^{\circ} \mathrm{CD}^{+}$in (B) bone marrow and (C) spleen. Representative stainings of B-1a cells in bone marrow and spleen are shown in Figure S2 in Supplementary Material. Figures represent 8- to 16-week-old mice with four to seven mice per group, and results are representative of at least two independent experiments. Graphs display mean + SD. Statistically significant differences between bumble, bumble heterozygotes, and wt mice are indicated by ${ }^{*} p<0.05$ and ${ }^{* *} p<0.01$ by Mann-Whitney test.

encoding PKC $\beta$ were found to lead to impaired antipolysaccharide antibody responses and reduced natural antibody levels, despite apparently normal B cell development (37).

Several clinical cases with mutations in NF- $\kappa$ B proteins have demonstrated important roles of both the classical and alternative NF- $\mathrm{KB}$ signaling pathways for B cell development and function in humans. Hypermorphic mutations in the gene encoding $\mathrm{I} \kappa \mathrm{B} \alpha$ lead to impaired phosphorylation-driven degradation of the mutant protein and thereby reduced NF- $\kappa B$ signaling (38). Hypermorphic heterozygous mutations in $\mathrm{I} \kappa \mathrm{B} \alpha$ cause ectodermal dysplasia with immunodeficiency as evidenced by recurrent severe infections $(38,39)$. These patients have increased numbers of $\mathrm{B}$ and $\mathrm{T}$ cells, but display both $\mathrm{B}$ and $\mathrm{T}$ cell functional defects (39). Notably, the patient symptoms and lymphocyte functional defects could to a large extent be reproduced when introducing one of the hypermorphic I $\mathrm{B} \alpha \alpha$ mutations (S32I) to mice (33). Similar symptoms to I $\mathrm{B} \alpha$ hypermorphs are evident in patients with NEMO deficiency and B cells from these patients do not respond to CD40 ligation (40). More recently, several patients with mutations in the CBM complex have been described. Combined immunodeficiency (CID) resulting from impaired classical NF- $\kappa \mathrm{B}$ signaling due to CARMA1 deficiency was associated with hypogammaglobulinaemia, impaired BAFF-R expression and a block of B cell maturation at the transitional B cell stage $(41,42)$. Human MALT1 deficiency, also manifested by CID, was associated with lack of MZB cells and failure to respond to Pneumovax vaccination $(43,44)$, a phenotype that is very similar to that seen in the corresponding mouse model (45). Rapid advances 


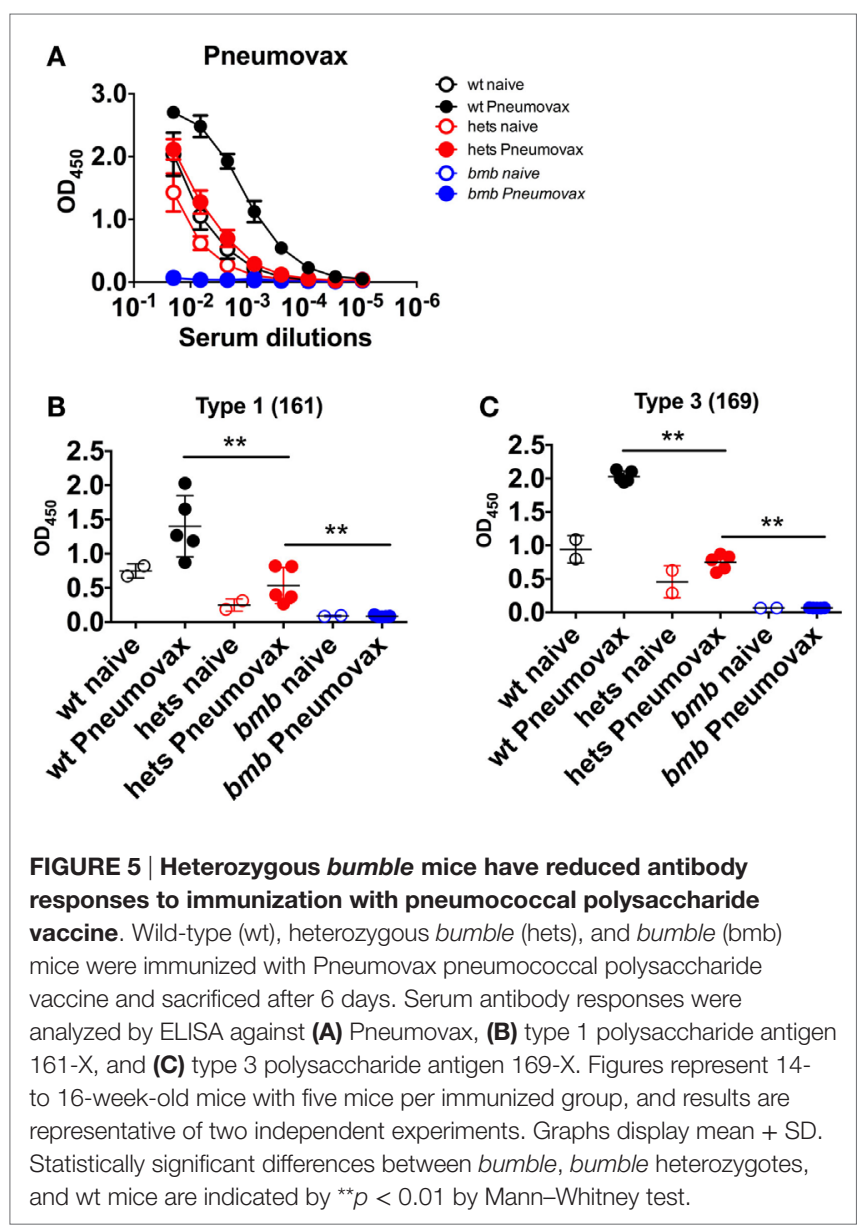

in identifying genes underlying human immunodeficiencies will reveal if also IкBNS plays a role in this disease group.

So far, there are few reports of heterozygous mutations in the NF-KB pathway leading to immunodeficiency in humans. Heterozygous gain-of-function mutations in the gene encoding CARMA1 were shown to result in constitutive NF- $\mathrm{KB}$ activity and are manifested by lymphocytosis but impaired memory B cells and low TI-2 responses $(46,47)$. It is interesting to speculate if

\section{REFERENCES}

1. Baumgarth $\mathrm{N}$. The double life of a B-1 cell: self-reactivity selects for protective effector functions. Nat Rev Immunol (2011) 11:34-46. doi:10.1038/nri2901

2. Rauch PJ, Chudnovskiy A, Robbins CS, Weber GF, Etzrodt M, Hilgendorf I, et al. Innate response activator B cells protect against microbial sepsis. Science (2012) 335:597-601. doi:10.1126/science.1215173

3. Cerutti A, Cols M, Puga I. Marginal zone B cells: virtues of innate-like antibodyproducing lymphocytes. Nat Rev Immunol (2013) 13:118-32. doi:10.1038/nri3383

4. O'Garra A, Chang R, Go N, Hastings R, Haughton G, Howard M. Ly-1 B (B-1) cells are the main source of B cell-derived interleukin 10. Eur J Immunol (1992) 22:711-7. doi:10.1002/eji.1830220314

5. Rosser EC, Mauri C. Regulatory B cells: origin, phenotype, and function. Immunity (2015) 42:607-12. doi:10.1016/j.immuni.2015.04.005

6. Maseda D, Candando KM, Smith SH, Kalampokis I, Weaver CT, Plevy SE, et al. Peritoneal cavity regulatory B cells (B10 cells) modulate IFN-gamma+CD4+ $\mathrm{T}$ cell numbers during colitis development in mice. J Immunol (2013) 191:2780-95. doi:10.4049/jimmunol.1300649 heterozygous mutations in genes encoding components of $\mathrm{BCR}$ signaling, including classical NF-kB pathway mediators, may contribute to the observed variability in antipolysaccharide immune responses in the human population $(48,49)$. We describe here that a heterozygous mutation in the nfkbid gene encoding the atypical IкB protein IкBNS led to reduced steady state IgM and IgG3 antibody levels and impaired response to vaccination with TI-2 antigens in mice. Heterozygous mutations in genes of the NF- $\mathrm{kB}$ pathway could potentially lead to haploinsufficiency for $B$ cell function, resulting in lower antibody responses to vaccination and increased susceptibility to infection, which should be considered in future studies.

\section{AUTHOR CONTRIBUTIONS}

GKP designed and performed the experiments and wrote the manuscript. MÁ, JS, and SK performed the experiments. CA and $\mathrm{BB}$ designed the experiments. GKH designed the experiments and wrote the manuscript. All authors have approved the manuscript.

\section{ACKNOWLEDGMENTS}

We are grateful to the personnel at the animal facility at the Department of Microbiology, Tumor and Cell Biology at the Karolinska Institutet. This work was supported by grants from the Bill \& Melinda Gates Foundation (GKH and BB), the Swedish Research Council (GKH), and David och Astrid Hageléns stiftelse (GKP).

\section{SUPPLEMENTARY MATERIAL}

The Supplementary Material for this article can be found online at http://journal.frontiersin.org/article/10.3389/fimmu.2016.00065

FIGURE S1 | Gating strategy for identifying transitional and progenitor B cells. (A) Representative staining of wild type splenocytes for transitional B cells $\left(\mathrm{CD}^{+}{ }^{+} \mathrm{B} 22 \mathrm{O}^{+}\right)$and the transitional $\mathrm{B}$ cell populations gated as indicated. (B) Representative staining of wild type bone marrow for progenitor and mature $\mathrm{B}$ cell populations. Pro B $\left(B 220^{+} \mathrm{CD} 43^{+} \mathrm{CD} 19^{+} \mathrm{CD} 93^{+}\right)$, pre B $\left(B 220^{+} \mathrm{CD} 43-\lg M-C D 93^{+}\right)$, immature $\mathrm{B}\left(\mathrm{B} 22 \mathrm{O}^{+} \mathrm{CD} 43^{-} \operatorname{lgM}^{+} \mathrm{CD} 93^{+}\right)$, and mature $\mathrm{B}$ cells $\left(\mathrm{B} 22 \mathrm{O}^{+} \mathrm{CD} 43^{-} \lg \mathrm{M}^{+} \mathrm{CD} 93^{-}\right)$.

FIGURE S2 | Representative stainings of bone marrow and spleen B-1a cells. B-1a cells were identified as CD93-IgM+CD19hiB220loCD5+ in (A) bone marrow and (B) spleen.

7. Martin F, Oliver AM, Kearney JF. Marginal zone and B1 B cells unite in the early response against T-independent blood-borne particulate antigens. Immunity (2001) 14:617-29. doi:10.1016/S1074-7613(01)00129-7

8. Hsu MC, Toellner KM, Vinuesa CG, Maclennan IC. B cell clones that sustain longterm plasmablast growth in T-independent extrafollicular antibody responses. Proc Natl Acad Sci U S A (2006) 103:5905-10. doi:10.1073/pnas.0601502103

9. Hayakawa K, Hardy RR, Herzenberg LA, Herzenberg LA. Progenitors for Ly-1 B cells are distinct from progenitors for other B cells. J Exp Med (1985) 161:1554-68. doi:10.1084/jem.161.6.1554

10. Yoshimoto M, Montecino-Rodriguez E, Ferkowicz MJ, Porayette P, Shelley WC, Conway SJ, et al. Embryonic day 9 yolk sac and intra-embryonic hemogenic endothelium independently generate a B-1 and marginal zone progenitor lacking B-2 potential. Proc Natl Acad Sci U S A (2011) 108:1468-73. doi:10.1073/pnas.1015841108

11. Allman D, Lindsley RC, Demuth W, Rudd K, Shinton SA, Hardy RR. Resolution of three nonproliferative immature splenic B cell subsets reveals multiple selection points during peripheral B cell maturation. JImmunol (2001) 167:6834-40. doi:10.4049/jimmunol.167.12.6834 
12. Saito T, Chiba S, Ichikawa M, Kunisato A, Asai T, Shimizu K, et al. Notch2 is preferentially expressed in mature B cells and indispensable for marginal zone B lineage development. Immunity (2003) 18:675-85. doi:10.1016/ S1074-7613(03)00111-0

13. Srivastava B, Quinn WJ III, Hazard K, Erikson J, Allman D. Characterization of marginal zone B cell precursors. J Exp Med (2005) 202:1225-34. doi:10.1084/ jem.20051038

14. Montecino-Rodriguez E, Leathers H, Dorshkind K. Identification of a B-1 B cell-specified progenitor. Nat Immunol (2006) 7:293-301. doi:10.1038/ni1301

15. Pedersen GK, Adori M, Khoenkhoen S, Dosenovic P, Beutler B, Karlsson Hedestam GB. B-1a transitional cells are phenotypically distinct and are lacking in mice deficient in IkappaBNS. Proc Natl Acad Sci U S A (2014) 111(39):E4119-26. doi:10.1073/pnas.1415866111

16. Gerondakis S, Siebenlist U. Roles of the NF-kappaB pathway in lymphocyte development and function. Cold Spring Harb Perspect Biol (2010) 2:a000182. doi:10.1101/cshperspect.a000182

17. Li Q, Verma IM. NF-kappaB regulation in the immune system. Nat Rev Immunol (2002) 2:725-34. doi:10.1038/nri968

18. Didonato JA, Hayakawa M, Rothwarf DM, Zandi E, Karin M. A cytokineresponsive IkappaB kinase that activates the transcription factor NF-kappaB. Nature (1997) 388:548-54. doi:10.1038/41493

19. Hoffmann A, Baltimore D. Circuitry of nuclear factor kappaB signaling. Immunol Rev (2006) 210:171-86. doi:10.1111/j.0105-2896.2006.00375.x

20. Bonizzi G, Karin M. The two NF-kappaB activation pathways and their role in innate and adaptive immunity. Trends Immunol (2004) 25:280-8. doi:10.1016/j.it.2004.03.008

21. Schuster M, Annemann M, Plaza-Sirvent C, Schmitz I. Atypical IkappaB proteins - nuclear modulators of NF-kappaB signaling. Cell Commun Signal (2013) 11:23. doi:10.1186/1478-811X-11-23

22. Pedersen GK, Adori M, Karlsson Hedestam GB. NF-kappaB signaling in B-1 cell development. Ann N Y Acad Sci (2015) 1362(1):39-47. doi:10.1111/ nyas. 12800

23. Cariappa A, Liou HC, Horwitz BH, Pillai S. Nuclear factor kappa B is required for the development of marginal zone B lymphocytes. J Exp Med (2000) 192:1175-82. doi:10.1084/jem.192.8.1175

24. Tusche MW, Ward LA, Vu F, McCarthy D, Quintela-Fandino M, Ruland J, et al. Differential requirement of MALT1 for BAFF-induced outcomes in B cell subsets. J Exp Med (2009) 206:2671-83. doi:10.1084/jem.20091802

25. Zhang X, Paun A, Claudio E, Wang H, Siebenlist U. The tumor promoter and NF-kappaB modulator Bcl-3 regulates splenic B cell development. J Immunol (2013) 191:5984-92. doi:10.4049/jimmunol.1300611

26. Hovelmeyer N, Worns MA, Reissig S, Adams-Quack P, Leclaire J, Hahn M, et al. Overexpression of Bcl-3 inhibits the development of marginal zone B cells. Eur J Immunol (2014) 44:545-52. doi:10.1002/eji.201343655

27. Touma M, Keskin DB, Shiroki F, Saito I, Koyasu S, Reinherz EL, et al. Impaired B cell development and function in the absence of IkappaBNS. JImmunol (2011) 187:3942-52. doi:10.4049/jimmunol.1002109

28. Arnold CN, Pirie E, Dosenovic P, McInerney GM, Xia Y, Wang N, et al. A forward genetic screen reveals roles for Nfkbid, Zeb1, and Ruvbl2 in humoral immunity. Proc Natl Acad Sci U S A (2012) 109:12286-93. doi:10.1073/ pnas.1209134109

29. Sha WC, Liou HC, Tuomanen EI, Baltimore D. Targeted disruption of the p50 subunit of NF-kappa B leads to multifocal defects in immune responses. Cell (1995) 80:321-30. doi:10.1016/0092-8674(95)90415-8

30. Ruland J, Duncan GS, Elia A, Del Barco Barrantes I, Nguyen L, Plyte S, et al. Bcl10 is a positive regulator of antigen receptor-induced activation of NF-kappaB and neural tube closure. Cell (2001) 104:33-42. doi:10.1016/ S0092-8674(01)00189-1

31. Egawa T, Albrecht B, Favier B, Sunshine MJ, Mirchandani K, O’brien W, et al. Requirement for CARMA1 in antigen receptor-induced NF-kappa B activation and lymphocyte proliferation. Curr Biol (2003) 13:1252-8. doi:10.1016/ S0960-9822(03)00491-3

32. Xue L, Morris SW, Orihuela C, Tuomanen E, Cui X, Wen R, et al. Defective development and function of Bcl10-deficient follicular, marginal zone and B1 B cells. Nat Immunol (2003) 4:857-65. doi:10.1038/ni963

33. Mooster JL, Le Bras S, Massaad MJ, Jabara H, Yoon J, Galand C, et al. Defective lymphoid organogenesis underlies the immune deficiency caused by a heterozygous S32I mutation in IkappaBalpha. J Exp Med (2015) 212:185-202. doi:10.1084/jem.20140979
34. Woodland RT, Schmidt MR. Homeostatic proliferation of B cells. Semin Immunol (2005) 17:209-17. doi:10.1016/j.smim.2005.02.006

35. Newton K, Dixit VM. Mice lacking the CARD of CARMAl exhibit defective B lymphocyte development and impaired proliferation of their B and T lymphocytes. Curr Biol (2003) 13:1247-51. doi:10.1016/ S0960-9822(03)00458-5

36. Gaide O, Favier B, Legler DF, Bonnet D, Brissoni B, Valitutti S, et al. CARMA1 is a critical lipid raft-associated regulator of TCR-induced NF-kappa B activation. Nat Immunol (2002) 3:836-43. doi:10.1038/ni830

37. Teh CE, Horikawa K, Arnold CN, Beutler B, Kucharska EM, Vinuesa CG, et al. Heterozygous mis-sense mutations in Prkcb as a critical determinant of anti-polysaccharide antibody formation. Genes Immun (2013) 14:223-33. doi:10.1038/gene.2013.11

38. Courtois G, Smahi A, Reichenbach J, Doffinger R, Cancrini C, Bonnet M, et al. A hypermorphic IkappaBalpha mutation is associated with autosomal dominant anhidrotic ectodermal dysplasia and $\mathrm{T}$ cell immunodeficiency. J Clin Invest (2003) 112:1108-15. doi:10.1172/JCI18714

39. Janssen R, Van Wengen A, Hoeve MA, Ten Dam M, Van Der Burg M, Van Dongen J, et al. The same IkappaBalpha mutation in two related individuals leads to completely different clinical syndromes. J Exp Med (2004) 200:559-68. doi:10.1084/jem.20040773

40. Jain A, Ma CA, Liu S, Brown M, Cohen J, Strober W. Specific missense mutations in NEMO result in hyper-IgM syndrome with hypohydrotic ectodermal dysplasia. Nat Immunol (2001) 2:223-8. doi:10.1038/85277

41. Greil J, Rausch T, Giese T, Bandapalli OR, Daniel V, Bekeredjian-Ding I, et al. Whole-exome sequencing links caspase recruitment domain 11 (CARD11) inactivation to severe combined immunodeficiency. J Allergy Clin Immunol (2013) 131:1376-83.e1373. doi:10.1016/j.jaci.2013.02.012

42. Stepensky P, Keller B, Buchta M, Kienzler AK, Elpeleg O, Somech R, et al. Deficiency of caspase recruitment domain family, member 11 (CARD11), causes profound combined immunodeficiency in human subjects. J Allergy Clin Immunol (2013) 131:477-485.e471. doi:10.1016/j.jaci.2012.11.050

43. Jabara HH, Ohsumi T, Chou J, Massaad MJ, Benson H, Megarbane A, et al. A homozygous mucosa-associated lymphoid tissue 1 (MALT1) mutation in a family with combined immunodeficiency. J Allergy Clin Immunol (2013) 132:151-8. doi:10.1016/j.jaci.2013.04.047

44. McKinnon ML, Rozmus J, Fung SY, Hirschfeld AF, Del Bel KL, Thomas L, et al. Combined immunodeficiency associated with homozygous MALT1 mutations. J Allergy Clin Immunol (2014) 133:1458-62, 1462.e1451. doi:10.1016/j. jaci.2013.10.045

45. Ruefli-Brasse AA, French DM, Dixit VM. Regulation of NF-kappaBdependent lymphocyte activation and development by paracaspase. Science (2003) 302:1581-4. doi:10.1126/science.1090769

46. Snow AL, Xiao W, Stinson JR, Lu W, Chaigne-Delalande B, Zheng L, et al. Congenital B cell lymphocytosis explained by novel germline CARD11 mutations. J Exp Med (2012) 209:2247-61. doi:10.1084/jem.20120831

47. Brohl AS, Stinson JR, Su HC, Badgett T, Jennings CD, Sukumar G, et al. Germline CARD11 mutation in a patient with severe congenital B cell lymphocytosis. J Clin Immunol (2015) 35:32-46. doi:10.1007/s10875-014-0106-4

48. Konradsen HB, Henrichsen J, Wachmann H, Holm N. The influence of genetic factors on the immune response as judged by pneumococcal vaccination of mono- and dizygotic Caucasian twins. Clin Exp Immunol (1993) 92:532-6. doi:10.1111/j.1365-2249.1993.tb03433.x

49. Schutz K, Hughes RG, Parker A, Quinti I, Thon V, Cavaliere M, et al. Kinetics of IgM and IgA antibody response to 23-valent pneumococcal polysaccharide vaccination in healthy subjects. J Clin Immunol (2013) 33:288-96. doi:10.1007/ s10875-012-9792-y

Conflict of Interest Statement: The authors declare that the research was conducted in the absence of any commercial or financial relationships that could be construed as a potential conflict of interest.

Copyright ( $\odot 2016$ Pedersen, Ádori, Stark, Khoenkhoen, Arnold, Beutler and Karlsson Hedestam. This is an open-access article distributed under the terms of the Creative Commons Attribution License (CC BY). The use, distribution or reproduction in other forums is permitted, provided the original author(s) or licensor are credited and that the original publication in this journal is cited, in accordance with accepted academic practice. No use, distribution or reproduction is permitted which does not comply with these terms. 